Original
Article

\section{Effect of mobile phone electromagnetic waves on rat testis and the possible ameliorating role of Naringenin : A histological study}

\author{
Eman Abas Farag and Marwa Mohamed Yousry
}

Department of Histology, Faculty of Medicine, Cairo University, Cairo, Egypt

\begin{abstract}
Introduction: With increasing the use of cell phones, the interest of examining the hazards that could affect health of people, which may or may not lead to cancer, infertility, or birth defects, was elevated. Recently, a natural flavonoid compound, Naringenin (NG) had received considerable attention as an antioxidant.

Aim of the work: Evaluating the effects of mobile phone use on the testes of adult rats, the progress of spontaneous recovery and the protective role of NG supplementation against these effects.

Materials and Methods: Twenty-four adult male albino rats were equally divided into four groups; control (I), (II) mobile, (III) mobile-NG and (IV) recovery. Mobile group exposed to $900 \mathrm{MHz}$ continuous RF-EMW emitted by talk mode for one hour daily for 8 weeks. Mobile-NG group exposed to RF-EMW like group III for 8 weeks concomitant with NG treatment $50 \mathrm{mg} / \mathrm{kg}$ /day orally. While recovery group exposed to the same RF-EMW for 8 weeks then kept unexposed for another 8 weeks for recovery. Serum levels of testosterone hormone, epididymal sperm counts and testicular malondialdehyde (MDA) level were measured. Testicular sections were stained with H\&E and immunohistochemical stains for PCNA, p53, CX43 and $\mathrm{AR}$, that were subjected to morphometric and statistically analysis.

Results: Deterioration of histological architecture of testes and biochemical and morphometric parameters were recorded in mobile group. However, preservation of the testicular histological structure and restoration of the normal biochemical and morphometric parameters were obvious in group IV. On the other hand, the recovery group showed incomplete improvement where some testicular affection was noted.

Conclusion: Mobile phones might have injurious effects on testes that partially recovered after stoppage of exposure to EMW. However, NG co-administration was protective.
\end{abstract}

Received: 31 October 2017, Accepted: 11 December 2017

Key Words: AR, CX43, mobile phone, naringenin, PCNA, p53, rat, testis.

Corresponding Author: Marwa Mohamed Yousry, Department of Histology, Faculty of Medicine, Cairo University, Cairo, Egypt, Tel.: +201006763862, E-mail: marwa.yousry@kasralainy.edu.eg

ISSN: 1110-0559, Vol. 41, No.1

\section{INTRODUCTION}

In Egypt, the mobile penetration rate exceeds $112 \%$. This means that almost each Egyptian citizen posses a mobile device ${ }^{[1]}$. Mobile phones operate between $800-2200 \mathrm{MHz}$ frequency bands emit radiofrequency electromagnetic waves (RF-EMWs). Human bodies act as antennas that absorb the radiation convert it into alternating cross-current $^{[2]}$. The adverse effects of RF- EMWs on heart, blood pressure, brain and endocrine system were widely reported ${ }^{[3]}$. Usage of mobile phones is also associated with many health problems like neck pain, earache, tinnitus, morning tiredness, headache, fatigue, painful fingers, eye symptoms, and restlessness sleep disturbance ${ }^{[4]}$.

The use of mobile phones is more common in young middle aged males who usually carry them in their pockets, close to the scrotal area. This raised the public concerns about interaction of mobile phone emitted electromagnetic waves (EMWs) with the male reproductive organs, especially testes ${ }^{[5,6]}$.

Naringenin (NG; 4, 5, 7-trihydroxyflavone) a glycine form of naringin, is a type of natural flavonoid compound $^{[7]}$. It widely exists in a variety of fruits such as grapefruit, citrus fruits, tomatoes, cherries and $\operatorname{cocoa}^{[8]}$. Onehalf orange and one-half mandarin provide $30 \mathrm{mg}$ of $\mathrm{NG}^{[9]}$. Naringenin has wide range of biological pharmacological activities as anti-inflammatory ${ }^{[10]}$, anticancer ${ }^{[11]}$, antiatherogenic $^{[12]}$ and antioxidant ${ }^{[13]}$. It has also been reported to be hepatoprotective $\mathrm{e}^{[14]}$, cardioprotective ${ }^{[15]}$ and renoprotective $\mathrm{e}^{[16]}$. Recently, NG protective effect against testicular toxicity induced by cisplatin (chemotherapeutic) $)^{[17]}$ and permethrin (insecticide) was investigated ${ }^{[18]}$.

Thus, this study aimed to investigate the effect of mobile phone use on the adult rat's testes, examine the recovery response after stoppage of exposure and evaluate 
the efficacy of NG supplementation in protecting this effect using serological, histological and immunohistochemical methods.

\section{MATERIALS AND METHODS}

\section{I) Animals:}

Twenty-four adult male albino rats (180 - 200 grams, 12 weeks old) were used in this study. Animal care was provided by laboratory animal house unit of Kasr Al-Ainy, Faculty of Medicine, Cairo University. Rats were provided with ordinary rat chow, bred at controlled temperature $\left(24 \pm 1^{\circ} \mathrm{C}\right)$, with normal light-dark cycle. All animals were kept under the same environmental conditions and had free access to water and food.

\section{II) Experimental design:}

Rats were randomly divided into four groups, 6 rats each:

* Control group (group I): subdivided equally into:

- Subgroup Ia: rats exposed to mobile without battery for 8 weeks.

- Subgroup Ib: rats exposed to mobile without battery simultaneously with administration of corn oil $(0.5 \mathrm{ml} /$ day $)$ (NG solvent) for 8 weeks.

- Subgroup Ic: rats exposed to mobile without battery for 8 weeks then kept unexposed for another 8 weeks.

* Mobile group (group II): rats exposed to $900 \mathrm{MHz}$ continuous RF-EMWs fields emitted by talk mode for one hour every day for 8 weeks ${ }^{[19]}$.

* Mobile-NG group (group III): rats exposed to mobile phone RF-EMWs similar to group II for 8 weeks concomitant with NG treatment $(50 \mathrm{mg} / \mathrm{kg} /$ day $)$ dissolved in $0.5 \mathrm{ml}$ corn oil orally once daily through gastric gavage for 8 weeks ${ }^{[18]}$. Naringenin was supplied as a powder (CAS No. 67604-48-2) (Sigma-Aldrich, St. Louis, MO, United States).

* Recovery group (group IV): rats exposed to the same RFEMWs as in group II for 8 weeks then kept unexposed for another 8 weeks for recovery.

\section{III) Experimental procedure:}

\section{1-Mobile phone RF-EMWs exposure:}

Animals of control and experimental groups were housed in polycarbonate cages measured $30 \times 40 \times 40$ $\mathrm{cm}(\mathrm{W} \times \mathrm{L} \times \mathrm{H})$. Only rats in groups II, III and IV were continually exposed to RF-EMWs emitted by talk mode for one hour from mobile test phones (model NOKIA 3110; Nokia Mobile Phones Ltd.). The frequency of the phone used was $900 \mathrm{MHz}$, pulsed at GSM (global system for mobile). The mobile phone was situated in the center of the cage at a distance $3 \mathrm{~cm}$ between mobile phone and cage floor ${ }^{[19]}$.

\section{2- Biochemical investigation:}

At the end of the experiment, the following investigations were done at Biochemistry Department, Faculty of Medicine, Cairo University:
- Tail vein blood samples were collected in heparinized capillary tubes, for measurement of serum levels of testosterone hormone (TH) by radioimmunoassay using commercial kit from Diagnostic Products Co. (Los Angeles, CA, USA).

- Animals from all groups were then sacrificed under anaesthesia by intraperitoneal injection of ketamine $(90 \mathrm{mg} / \mathrm{kg}) /$ xylazine $(15 \mathrm{mg} / \mathrm{kg})^{[20]}$.

- For measurement of total sperms count, both right and left cauda epididymides were dissected. One $\mathrm{cm}$ incision was done to release all sperms in collection vial containing $5 \mathrm{ml}$ bovine serum albumin (BSA)-Hanks solution. Then, this fluid was filtered through a nylon mesh sieve and diluted with formalinized saline $(0.1 \mathrm{ml}$ of filtrate in 1.9 $\mathrm{ml}$ saline). Epididymal sperm counts were done using the hemocytometer. The measured sperm number was multiplied by the dilution factor to yield the total sperm count $^{[21]}$.

- For measurement of malondialdehyde (MDA) level, lipid peroxidation indicator, (Left testes specimens were dissected and homogenized in ten volumes of ice-cold medium of $50 \mathrm{mM}$ Tris-HCl ( $\mathrm{pH} \mathrm{7.4).} \mathrm{The} \mathrm{homogenate}$ was incubated with $1 \mathrm{~mL}$ of $10 \%$ trichloroacetic acid and 1 $\mathrm{mL}$ of $0.67 \%$ thiobarbituric acid at $100 \mathrm{C}$ for $30 \mathrm{~min}$. The MDA level was measured by using colorimetric assay kits (Biodiagnostic, Giza, Egypt) ${ }^{[22]}$.

\section{3- Light microscopic studies:}

Right testes specimens were fixed in Bouin's solution and embedded in Paraffin. Serial sections were cut at a thickness of $6 \mu \mathrm{m}$ and thereafter, stained with:

- Hematoxylin and Eosin stain ${ }^{[23]}$.

- Immunohistochemical staining:

1. PCNA, a marker for proliferating cells, is a rabbit polyclonal antibody (catalogue number ab15497, abcam, Cambridge, UK).

2. p53, a marker for apoptosis, is a rabbit polyclonal antibody (catalogue number ab131442, abcam, Cambridge, UK).

3. Connexin43 (CX43), the predominant gap junction protein in testes [24]: It is a rabbit polyclonal antibody (cat number ab11370, abcam, Cambridge, UK).

4. Androgen receptor (AR) that mediates the action of TH in testes ${ }^{[25]}$ : It is a rabbit polyclonal antibody (catalogue number ab74272, abcam, Cambridge, UK).

Immunostaining required pretreatment by boiling for 10 minutes in $10 \mathrm{Mm}$ citrate buffer (cat number AP 9003) pH 6 for antigen retrieval and leaving the sections to cool in room temperature for 20 minutes. Then, these sections were incubated for one hour with the primary antibodies. Immunostaining was completed by the use of Ultravision detection system (cat number TP - 015- HD).

Counterstaining was done using Mayer's hematoxylin 
(catalogue number TA- 060- MH) [26]. Citrate buffer, Ultravision detection system and Mayer's hematoxylin were purchased from Lab Vision Thermo Scientific (Fremont, California, USA).

\section{4- Morphometric study}

It included measurement of the following parameters:

- Mean number of PCNA immunopositive cells at a magnification of $\times 100$.

- Mean number of p53 immunopositive spermatogenic cells at a magnification of $\times 100$.

- Mean number of p53 immunopositive Leydig cells at a magnification of $\times 100$.

- Mean area percent of immunopositive reaction of CX43 antibody at a magnification of $\times 100$.

- Mean number of AR immunopositive Leydig cells at a magnification of $\times 100$.

- Mean height of spermatogenic epithelium that was measured in H\&E-stained sections at a magnification of $\times$ 100. For each seminiferous tubule (ST), four measurements were done in 4 quadrants to obtain its mean.

- Mean diagonal diameter of the nearly rounded STs that was measured in H\&E-stained sections at magnification $\times 100$. For each ST two measurements were done to obtain its mean.

All measurements were done in 10 non overlapping fields from different sections of each group. Image analysis was done using Leica Qwin 500 LTD software image analysis computer system (Cambridge, England) present at the Histology Department, Faculty of Medicine, Cairo University.

\section{5- Statistical analysis:}

The morphometric and biochemical measurements were expressed as mean \pm standard deviation (SD) and were analyzed statistically using one-way analysis of variance ANOVA, followed by "Tuckey" post hoc test. Results were considered significant when $\mathrm{P}$ value was $<$ 0.05 . Calculations were made on SPSS software (version 21.0. Armonk, NY, IBM Crop) ${ }^{[27]}$.

\section{RESULTS}

\section{General observation}

No deaths were observed in rats during the experiment.

All control subgroups showed similar biochemical and histological results so, they were collectively named control group.

\section{Biochemical results and statistical analysis (Table 1)}

At day 0 of the experiment there was non-significant difference between all studied groups regarding testicular MDA, serum testosterone hormone (TH) level and epididymal sperm count. At the end of the experiment, mobile and recovery groups showed significant increase in testicular MDA and significant decrease in serum TH level and epididymal sperm count compared to control group $(p<0.05)$. On the other hand, mobile-NG group expressed significant decrease in testicular MDA and significant increase in serum TH level and epididymal sperm count compared to mobile and recovery groups $(p<0.05)$ and non-significant difference versus control group. Additionally recovery group recorded non-significant difference compared to mobile group.

\section{Light microscopic results}

\section{- Hematoxylin and eosin stain:}

Testicular sections of the control group revealed closely packed seminiferous tubules (STs) with normal histological structure lined by spermatogenic cells and Sertoli cells. Spermatogenic cells included spermatogonia, primary spermatocytes, spermatids and spermatozoa. Spermatogonia appeared as small rounded cells with rounded nuclei resting on regular basement membrane. Primary spermatocytes were the largest spherical cells that had large rounded nuclei with partially condensed chromosomes. Spermatids appeared as small round cells with pale rounded nuclei and prominent nucleoli. Spermatozoa with deeply stained heads were also observed near the lumen of the tubules. Flattened, smooth musclelike myoid cells were found external to the basal lamina of the ST. Sertoli cells appeared as tall cells lodged between spermatogenic cells with triangular vesicular nuclei and prominent nucleoli. The interstitial tissue between the STs showed blood vessels and interstitial cells of Leydig, that appeared as large polygonal cells with vesicular nuclei and acidophilic cytoplasm contained small lipid droplets (Figs. 1A-1C).

In group II, examination of testicular sections demonstrated distorted histological architecture of some STs with widening of interstitial spaces. Some STs showed irregular basement membranes and detached spermatogenic cells leaving empty spaces. Apoptotic changes in the form of pyknotic or irregular darkly stained nuclei and deeply acidophilic cytoplasm were observed in most of spermatogenic cells. Other spermatogenic cells showed cytoplasmic vacuolation. In addition, some STs showed sloughed germ cells, homogenous acidophilic material and multinucleated giant cells. Interstitial tissue contained congested blood vessels and most of Leydig cells appeared with darkly stained nuclei (Figs. 2A-2D).

Regarding group III, testicular sections showed apparently normal packed STs lined by several layers of spermatogenic cells and Sertoli cells resting on regular basement membranes surrounded by myoid cells with flattened nuclei. Few empty spaces were still seen among spermatogenic epithelium. Interstitial spaces showed blood vessels and polygonal Leydig cells with pale nuclei and acidophilic vacuolated cytoplasm. However, few cells with darkly stained nuclei were observed (Figs. 3A-3C).

Testicular sections of recovery group recorded 
incomplete improvement where some apparently packed STs showed partial loss of spermatogenic cells. Some spermatogenic cells appeared with pyknotic nuclei and/or acidophilic cytoplasm either resting on regular or irregular basement membrane or detached leaving empty spaces. Other STs were still containing multinucleated giant cells. The interstitial tissue contained congested blood vessels and Leydig cells with pale or dark nuclei (Figs. 4A-4C).

\section{Immunohistochemical results}

\section{Immunohistochemical staining for PCNA:}

Examination of testicular sections of the control group and group III revealed PCNA positive immunoreaction that appeared as brown nuclear deposits in spermatogonia and primary spermatocytes. On the other hand, testicular sections of group II and group IV showed few positive immunoreactive spermatogonia and primary spermatocytes (Figs. 5A-5D).

\section{Immunohistochemical staining for p53:}

Sections of control group and group III stained with anti p53 showed positive brown nuclear immunoreaction in few spermatogenic cells and Leydig cells as well. However, those of group II showed many immunoreactive spermatogenic and Leydig cells as compared to the control. Regarding group IV, some positive immunoreactive spermatogenic and Leydig cells were observed (Figs. 6A-6D).

\section{Immunohistochemical staining for CX43:}

Sections of groups I and III stained with anti CX43 revealed positive immunoreaction in cell processes and cytoplasm of Sertoli cells as well as in Leydig cells. While, anti CX43 stained sections in group II and recovery group showed scanty immunoreactivity (Figs. 7A-7D).

\section{Immunohistochemical staining for AR:}

Testicular sections stained with anti-AR of different groups, revealed positive nuclear immunoreaction in Leydig, Sertoli and myoid cells. This reaction appeared in many Leydig cells of groups I and III. While in groups II and IV, some positive immunoreactive Leydig cells were noted (Figs. 8A-8D).

\section{Morphometric results (Table 2)}

The mean diagonal diameter of STs, height of spermatogenic epithelium, mean number of PCNA positive cells and AR immunopositive Leydig cells and mean area percent of CX43 positive immunoreaction showed a significant decrease in groups II and IV compared to control $(p<0.05)$. As regards the mean number of $\mathrm{p} 53$ positive spermatogenic and Leydig cells, groups II and IV showed significant increase. However, After 8 weeks of treatment with NG (group III), a significant decrease in the mean number of p53 positive cells and a significant increase in all other parameters were encountered compared to groups II and IV. Non-significant difference in all morphometric parameters was recorded in group III versus group I and in recovery group versus mobile group.

Table 1: Mean value \pm SD of biochemical parameters in all studied groups:

\begin{tabular}{lllll}
\hline Parameters & Group I & Group II & Group III & Group IV \\
\hline $\begin{array}{l}\text { Mean value of testicular } \\
\text { MDA (nmoL/mg tissue) }\end{array}$ & $1.71 \pm 0.42$ & $9.8 \pm 0.79^{*}$ & $2.69 \pm 0.25$ & $8.8 \pm 1.9^{*}$ \\
$\begin{array}{l}\text { Mean number of sperms } \\
\text { (number in millions/ml) }\end{array}$ & $1556.4 \pm 28.7$ & $721.58 \pm 11.3^{*}$ & $1457.5 \pm 168.3$ & $768.1 \pm 89.2^{*}$ \\
$\begin{array}{l}\text { Mean value of serum } \\
\text { testosterone (ng/mL) }\end{array}$ & $2.7 \pm 0.17$ & $0.92 \pm 0.09^{*}$ & $2.12 \pm 0.72$ & $1.5 \pm 0.712^{*}$ \\
\hline
\end{tabular}

* Significant $(p<0.05)$ as compared to groups I and III. 
Table 2: Mean value \pm SD of morphometric parameters in all studied groups:

\begin{tabular}{|c|c|c|c|c|}
\hline Parameters & Group I & Group II & Group III & Group IV \\
\hline Mean diagonal diameter of ST in $\mu \mathrm{m}$ & $391.2 \pm 2.8$ & $200.3 \pm 8.7^{*}$ & $379.6 \pm 13.24$ & $212.8 \pm 18.4^{*}$ \\
\hline $\begin{array}{l}\text { Mean height of spermatogenic epithelium } \\
\text { in } \mu \mathrm{m}\end{array}$ & $159.1 \pm 3.7$ & $74.6 \pm 2.3 *$ & $146.4 \pm 13.4$ & $84.9 \pm 16.4^{*}$ \\
\hline Mean number of PCNA positive cells & $39.6 \pm 2.4$ & $17.8 \pm 3.2 *$ & $33.9 \pm 8.2$ & $20.9 \pm 4.5^{*}$ \\
\hline $\begin{array}{l}\text { Mean number of p53 positive spermatogenic } \\
\text { cells }\end{array}$ & $9.9 \pm 2.3$ & $23.8 \pm 2.8^{*}$ & $11.2 \pm 2.65$ & $19.6 \pm 5.7 *$ \\
\hline Mean number of p53 positive Leydig cells & $2.9 \pm 0.73$ & $6.8 \pm 1.3^{*}$ & $4.1 \pm 0.9$ & $5.6 \pm 1.2 *$ \\
\hline Mean area percent of CX43 & $6.01 \pm 0.44$ & $2.34 \pm 0.12 *$ & $5.3 \pm 0.7$ & $3.03 \pm 0.8^{*}$ \\
\hline Mean number of AR positive Leydig cells & $30.8 \pm 2.5$ & $11.8 \pm 2.09 *$ & $26.9 \pm 6.6$ & $14.9 \pm 3.3 *$ \\
\hline
\end{tabular}

* Significant $(p<0.05)$ as compared to groups I and III.

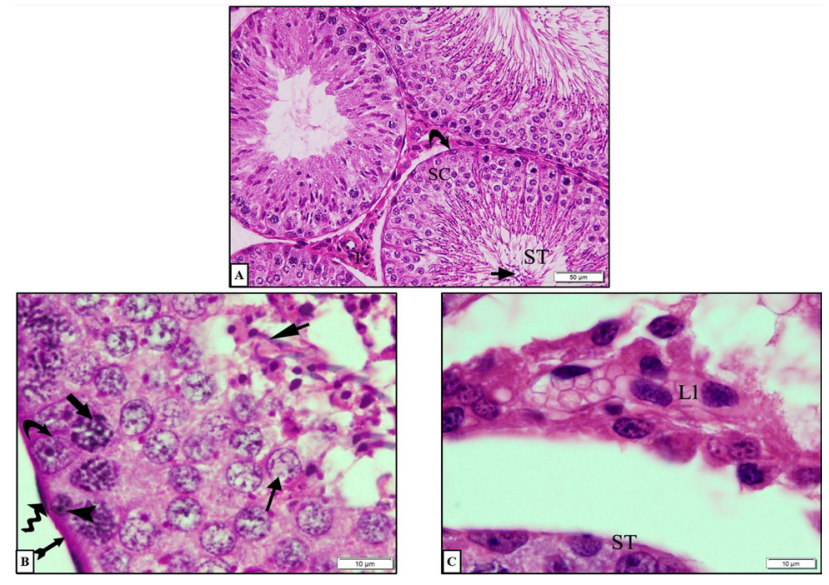

Fig. 1: Photomicrograph of control testicular sections showing: A: Closely packed seminiferous tubules (ST) lined by spermatogenic cells (SC) and Sertoli cell (curved arrow), with sperms (arrow with long arrowhead) in their lumens. Additionally interstitial tissue (I) between the seminiferous tubules is seen [H\&E, x200]. B: Sertoli cell (curved arrow) is a tall cell lodged between spermatogenic cells with triangular vesicular nucleus and prominent nucleolus also spermatogonium (arrowhead) resting on regular basement membrane (bifid arrow) appears as small rounded cell with rounded nucleus. Primary spermatocyte (thick arrow), the largest spherical cell having large rounded nuclei with partially condensed chromosomes is observed. Spermatid (thin arrow), small round cell shows pale rounded nucleus and prominent nucleolus. Sperms (arrow with long arrowhead) with deeply stained heads are also seen near the lumen of the tubules. External to the basal lamina of the ST, flattened myoid cell (zigzag arrow) is found [H\&E, x1000]. C: Leydig cells (L1) with vesicular nuclei and acidophilic vacuolated cytoplasm containing small lipid droplets and part of a seminiferous tubule (ST) are observed [H\&E, x1000].
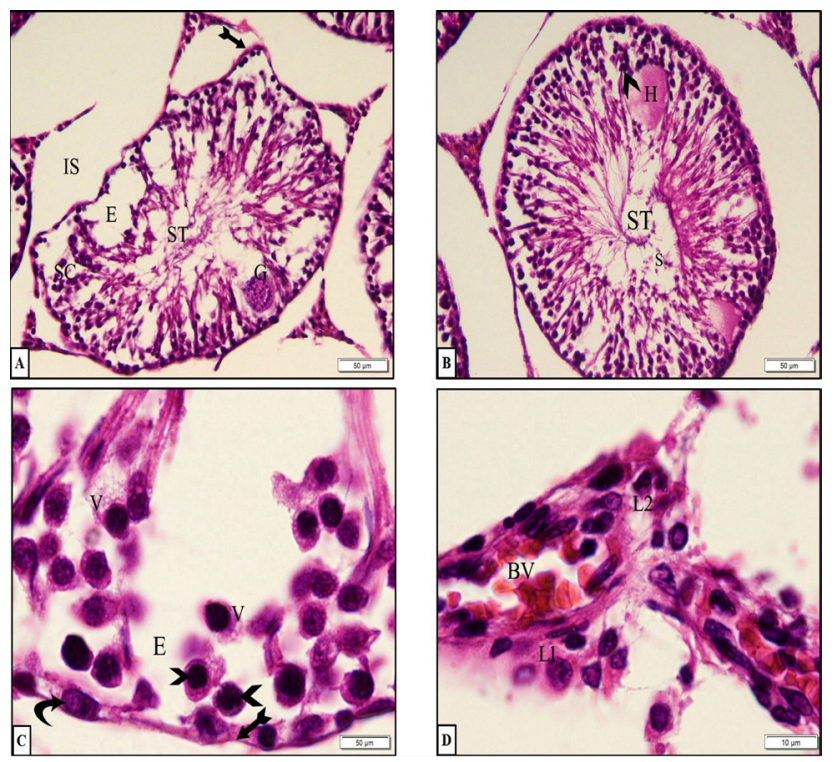

Fig. 2: Photomicrographs of mobile group testicular sections illustrating: A: Distorted ST, wide interstitial space (IS), irregular basement membrane (bifid arrow), detached spermatogenic cells (SC), empty spaces (E) and multinucleated giant cell (G) $[H \& E$, x200]. B: Seminiferous tubule (ST) with darkly stained nuclei of spermatogenic cells (bisected arrowhead), homogenous acidophilic material $(\mathrm{H})$ and sloughed germ cells (S) are demonstrated [H\&E, x200]. C: Spermatogenic cells appear with pyknotic or irregular darkly stained nuclei (bisected arrowheads) and cytoplasmic vacuolation (V). Note the presence of the empty spaces (E) and Sertoli cell (curved arrow) resting on irregular basement membrane (bifid arrow) [H\&E, x1000]. D: The interstitial tissue contains congested blood vessels (BV) and Leydig cells with darkly stained nuclei (L2), and other few ones with vesicular nuclei (L1) [H\&E, x1000]. 


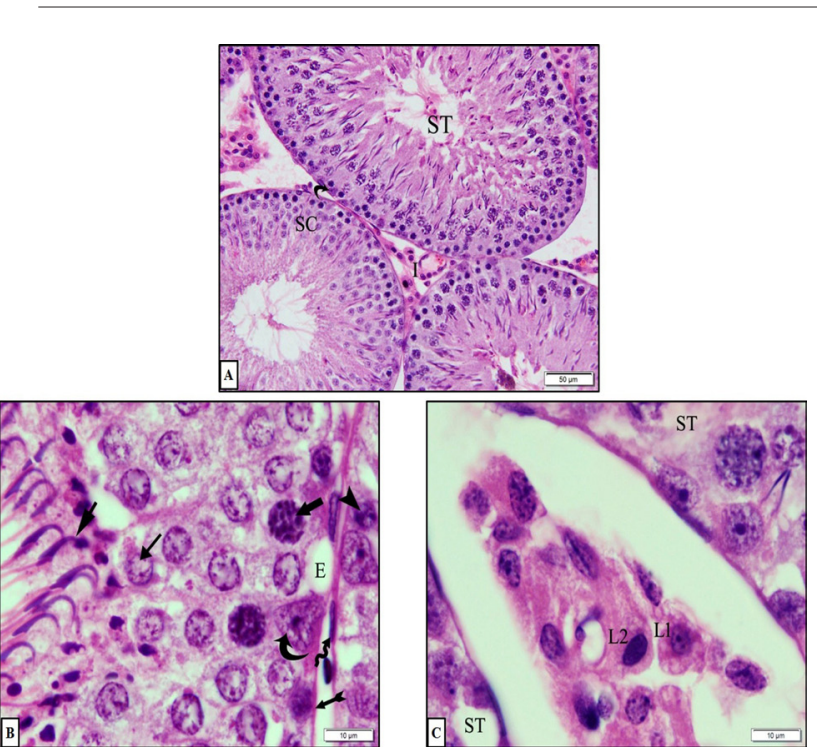

Fig. 3: Photomicrographs of mobile-NG group testicular sections demonstrating: A: Packed ST lined by spermatogenic cells (SC) and Sertoli cell (curved arrow) with the presence of interstitial tissue (I) in between ST [H\&E, x200]. B: Apparently normal Spermatogonia (arrowhead), primary spermatocyte (thick arrow), spermatid (thin arrow), sperm (arrow with long arrowhead), Sertoli cell (curved arrow) lying on regular basement membrane (bifid arrow) and myoid cell (zigzag arrow), however few empty spaces (E) among the spermatogenic epithelium are observed [H\&E, x1000]. C: Leydig cells (L1) show acidophilic vacuolated cytoplasm and vesicular nuclei and another Leydig cell (L2) exhibits darkly stained nucleus. Parts of STs are seen [H\&E, x1000].

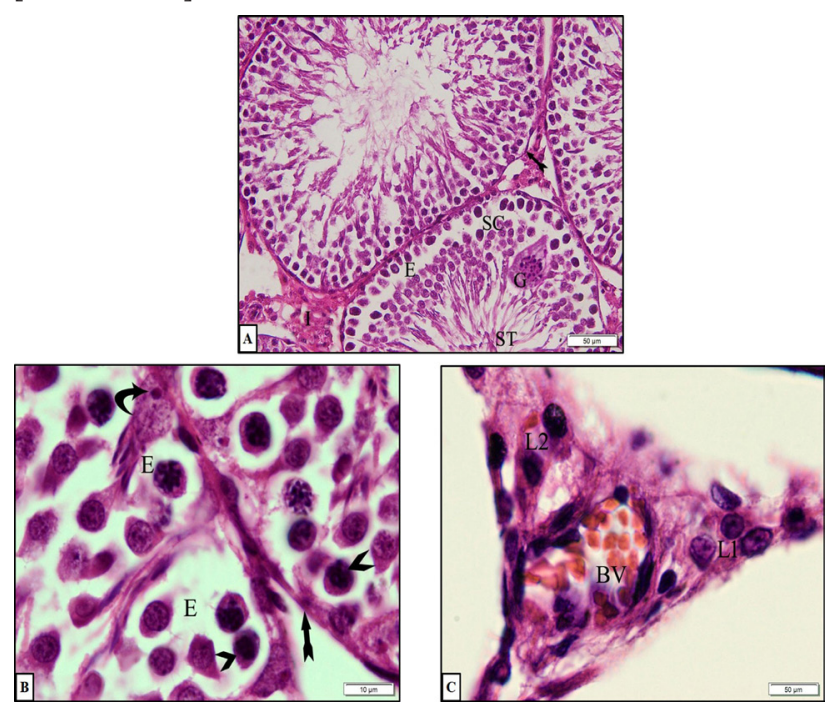

Fig. 4: Photomicrographs of recovery group testicular sections showing: A: Apparently packed ST with irregular basement membrane (bifid arrow), detached spermatogenic cells (SC), empty spaces (E), multinucleated giant cell $(\mathrm{G})$ and interstitial tissue (I) between the tubules [H\&E, x200]. B: Part of two STs demonstrating Sertoli cell (curved arrow) resting on regular basement membrane (bifid arrow), pyknotic spermatogenic cells (bisected arrowheads) and empty spaces (E) [H\&E, x1000]. C: Leydig cells with vesicular nuclei (L1) and others with darkly stained nuclei (L2) and congested blood vessel (BV) are illustrated [H\&E, x1000].
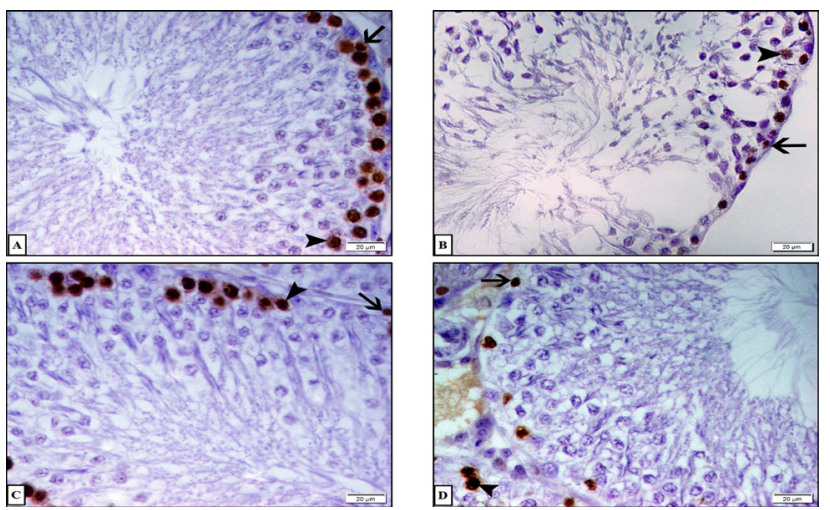

Fig. 5: Photomicrographs of PCNA immunostained testicular sections: A: Control group \& C: Group III illustrating positive nuclear immunoreaction in spermatogonia (arrow) and primary spermatocytes (arrowhead). B: Group II \& D: Group IV showing few positive spermatogonia (arrow) and primary spermatocytes (arrowhead) [x400].
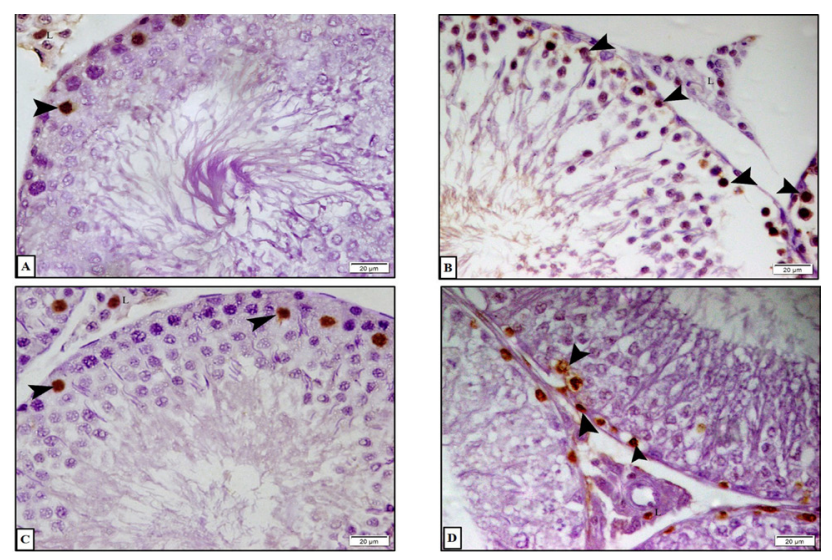

Fig. 6: Photomicrographs of p53 immunostained testicular sections: A: Control group \& C: Group III demonstrating positive nuclear immunoreaction in few spermatogenic cells (arrowhead) and Leydig cell (L). B: Group II showing many positive immunoreactive spermatogenic cells (arrowheads) and Leydig cells (L). D: Group IV showing some positive immunoreactive spermatogenic cells (arrowheads) and Leydig cell (L) [x400].
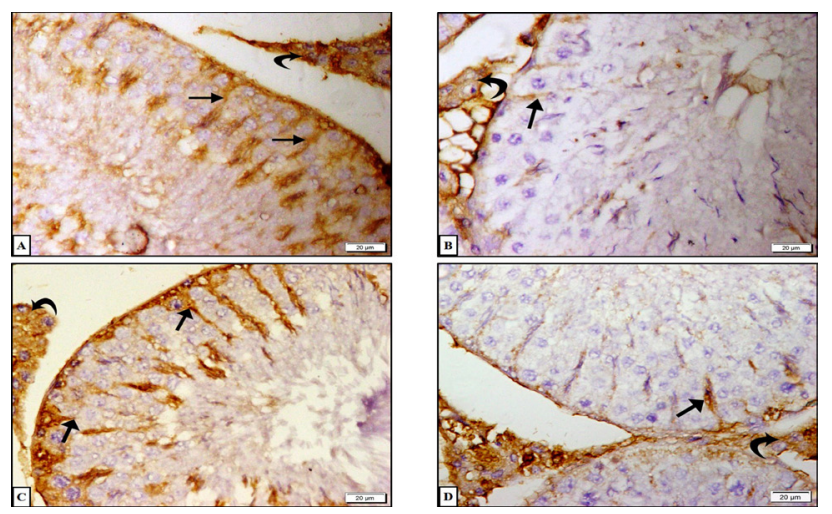

Fig. 7: Photomicrographs of CX43 immunostained testicular sections: A: Control group \& C: Group III, illustrating positive immunoreactivity in cytoplasm and processes of Sertoli cells (arrows) and Leydig cells (curved arrow). B: Group II \& D: Group IV demonstrating scanty positive immunoreaction in Sertoli cells (arrow) and Leydig cells (curved arrow) [x400]. 

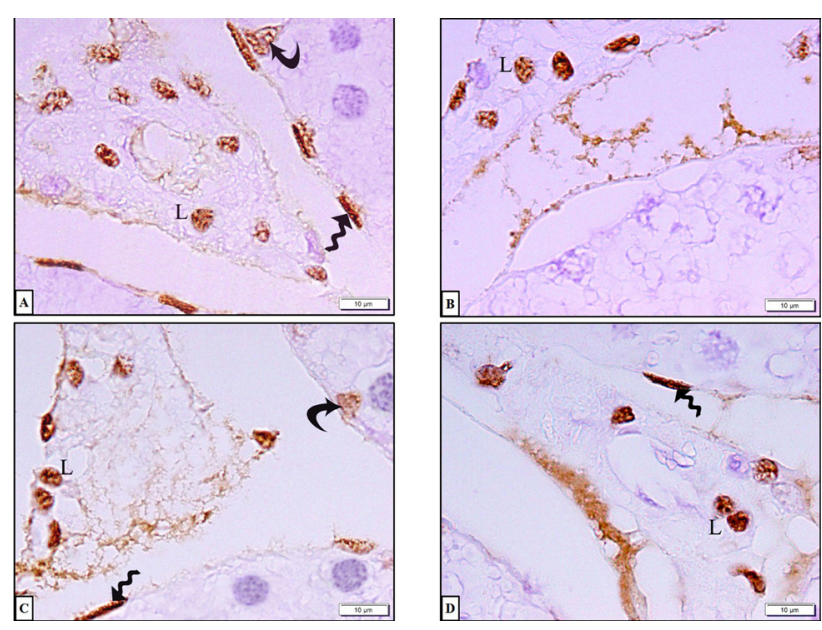

Fig. 8: Photomicrographs of AR immunostained testicular sections A: Control group \& C: Group III illustrating positive nuclear immunoreaction in many of Leydig cells (L), Sertoli cell (curved arrow) and myoid cells (zigzag arrow). B: Group II \& D: Group IV showing some positive immunoreactive Leydig cells (L). Additionally, positive immunoreactive myoid cells (zigzag arrow) are seen in D [x1000].

\section{DISCUSSION}

The evidence for the harmful effects of RF-EMWs on fertility remains controversial ${ }^{[28]}$. Several studies declared that cell phone usage led to decreased male fertility. Nonetheless, other studies showed no conclusive link between male infertility and cell phone usage ${ }^{[2]}$. Therefore, the first aim of the present study was to evaluate the consequences of increasing usage of mobile phones on testes.

The RF-EMWs may affect biological systems by increasing free radicals, which enhance mainly lipid peroxidation, and by changing the antioxidant defense systems of human tissues leading to $\operatorname{OS}^{[29]}$.

There's general agreement that, OS was implicated as one of the main culprit in male infertility ${ }^{[3]}$ and that EMWs can intensify the generation of OS and cause an imbalance between the production of reactive oxygen species (ROS) and their antioxidant defense system ${ }^{[30]}$. This could be enforced in the present work by the detection of the highest concentration of MDA in testicular tissues of group II.

The MDA is one of the most popular and reliable markers that determine OS in clinical situations ${ }^{[31]}$. It is produced by peroxidation of polyunsaturated fatty acids (PUFA). So, increased MDA level is considered as an important indicator of lipid peroxidation ${ }^{[32]}$ and subsequently, loss of membranes structures and functions ${ }^{[33]}$. Testes, being rich in PUFA and having high rates of metabolism and cell replication and poor antioxidant defenses, are much more vulnerable to peroxidation injury compared with other tissues ${ }^{[34]}$.
Increased MDA levels in rat testes following RF-EMWs exposure was similarly reported in former studies $[35,36]$.

In the present work, increased MDA in group II might explain the loss of histological architecture of STs that was supported by significant decrease in diameter of ST, height of lining spermatogenic epithelium, mean count of sperms and level of TH in comparison with the control. Similar features were previously reported ${ }^{[37,38]}$. This explanation was enforced by the ability of MDA to react with multiple biomolecules such as proteins or DNA leading to DNA damage, cell cycle arrest ${ }^{[32]}$, apoptosis of germ cell and consequently low sperm count following mobile phone radiation exposure ${ }^{[39]}$. The high susceptibility of spermatozoa to DNA damage was attributed to loss of their cytoplasm, which contains anti-oxidant enzymes, and consequently, loss of their capacity for DNA repair after spermiation $^{[40]}$. Hand in hand with previously mentioned results, Aitken et al., 2005 ${ }^{[41]}$ suggested that RF- EMWs might have a genotoxic effect on mitochondrial and nuclear genome in epididymal spermatozoa of mice exposed to 900 MHz RF- EMWs.

Exposure to EMF has adverse effects on the proliferation and differentiation of spermatogonia, which may be important in understanding the pathogenesis of EMFinduced male infertility ${ }^{[42,43]}$. Therefore, we used PCNA as a tool to assess spermatogenesis. The mean number of PCNA positive testicular germ cells was significantly reduced in group II indicating disruption in cell proliferation and spermatogenesis. This was in agreement with a former study in which exposure of rats to $900 \mathrm{MHz}$ RF- EMWs fields for one hour daily for 8 weeks resulted in significant decrease in PCNA expression ${ }^{[35]}$.

Another reason for low sperm count and for the detached spermatogenic epithelium and presence of exfoliated germ cells in the lumen of STs in group II could be the disruption of specialized connections between differentiating germ cells and Sertoli cells ${ }^{[44]}$. To emphasize this assumption, anti-CX43 antibodies was used being the predominant connexin in testis and essential for germ cell proliferation, differentiation, survival and late maturation of spermatocytes ${ }^{[45]}$. In addition to its involvement in the control of blood-testis barrier integrity ${ }^{[46]}$ and maintenance of Sertoli cell polarity, also it is the only CX expressed in Leydig cells ${ }^{[47]}$. Consistent with these reports, CX43 immunoreactivity in control group of the current study was observed mainly in Sertoli cells and in Leydig cells. On the other hand, these junctions were disrupted upon OS in group II as confirmed morphometrically by the significant decrease in CX43 area percent compared to the control. This finding was in accordance with ${ }^{[48]}$.

It was reported that Sertoli cells impairment in turn, led to subsequent changes or decrease in seminiferous tubule fluid secretion that contains appropriate nutritional and hormonal factors necessary to support spermatogenesis $^{[2]}$ and meiosis completion ${ }^{[49]}$. Such impairment shown in group II of the current study as 
defective expression of CX43-could result in metabolic disturbance in germ cells, vacuolation of their cytoplasm, germ cell death and shedding ${ }^{[50]}$. In addition, impaired phagocytic function of Sertoli cells could explain the presence of homogenous acidophilic material in some STs of the same group that resulted from hyalinization of the degenerated and exfoliated germ cells.

Moreover, appearance of multinucleated giant cells in the lumen of STs of this group suggested opening up of the cytoplasmic bridges between progeny of each cell division and fusion of their cellular contents ${ }^{[44]}$. These giant cells have been reported repeatedly in previous studies following RF - EMWs exposure ${ }^{[35,43]}$ and were assumed to be due to excessive apoptosis induced by OS via mitochondrial dysfunction ${ }^{[51]}$. During spermatogenesis, apoptosis in testicular germ cells is considered as a physiologic mechanism to limit the germ cell population to numbers that the Sertoli cells can support ${ }^{[52]}$. Regulation of germ cell apoptosis in normal testis is under control of the Bcl- 2 family, p53 and Fas-signaling pathway ${ }^{[53]}$. This assumption was supported in the present work by the apoptotic appearance and vacuolation seen in most of spermatogenic epithelium of group II that was enforced by increased expression of $\mathrm{p} 53$. These findings were similarly reported in prior studies ${ }^{[54]}$.

Widening of peritubular tissue observed in sections of group II could be attributed to the impaired spermatogenesis and the subsequent decrease in height of spermatogenic epithelium and diameter of STs as confirmed morphometrically. Some studies added that, the organization of the testicular tissue is affected by hormonal stimulation and referred this widening of the peritubular tissue to withdrawal of gonadotrophic stimulations that occurs after hypophysectomy ${ }^{[5]}$. This could be supported by several studies which clarified that EMWs could interfere with the endocrine regulation of spermatogenesis ${ }^{[2]}$ and by the significant decrease of serum testosterone level in group II in the present study versus control. This finding was reported formerly upon exposure of rats to RF-EMWs ${ }^{[56,30]}$.

Testosterone has stimulatory effect on protein synthesis in all types of testicular germ cells leading to sperm development ${ }^{[57]}$. It stimulates the conversion of round spermatids into elongated spermatids ${ }^{[58]}$. These actions of $\mathrm{TH}$ are exerted through androgen receptors (AR) and its signaling in the testis, is essential for spermatogenesis ${ }^{[25]}$. Since, germ cells do not express AR therefore, it is widely accepted that the requirement of $\mathrm{TH}$ for spermatogenesis is mediated by Leydig, Sertoli and myoid cells of the mature testis through expression of $\mathrm{AR}^{[59]}$. This provides an explanation for the nuclear immunoreactivity of AR that was detected in such cells of the control group of the present work.

Reduced serum TH level in group II in this study could be attributed to the impairment of Leydig cells in response to cell phone ${ }^{[2]}$ as they were considered among the most susceptible cells to EMWs ${ }^{[60]}$. Oxidative stress and EMWs could induce alteration in protein kinase $\mathrm{C}$ (PKC) enzyme complex that played a regulatory role in steroidogenesis in Leydig cells ${ }^{[61]}$ and through affection of the expression of mRNA for P450 cholesterol side chain lyase (the first enzyme in steroidogenesis in Leydig cells $)^{[62]}$. This assumption was supported in the present work by the apoptotic appearance and positive expression of p53 of many Leydig cells in group II. That was furtherly established by significant increase in number of $\mathrm{p} 53$ positive Leydig cells, decrease in number of AR immunopositive Leydig cells and serum TH. Additional enforcement was recorded from the results of other investigators who demonstrated decrease in serum $\mathrm{TH}$ levels and number of Leydig cells in rats exposed for 1 month to $900 \mathrm{MHZ}$ $\mathrm{EMWs}^{[37]}$.

Noteworthy, antioxidants such as melatonin, caffeic acid and phenyl ester prevented OS and apoptosis caused by RF-EMWs in different animal tissues ${ }^{[63,64]}$. Therefore, the second aim of the present work was to evaluate the potentiality of NG to protect the testes from the injurious effect of mobile phone. NG is a member of subgroup of flavanones that play important role in body health in terms of antioxidant and anti-inflammatory. NG has significant difference with other members of flavanones subgroups because it can bind to DNA ${ }^{[65]}$.

The protective effect of NG was evident in the current study in group III by the nearly normal histological structures of STs and interstitial tissues. In addition, the immune expression of PCNA, p53 and CX43 returned to a level almost close to the control with subsequent promotion of cell cycle progression. This was proved morphometrically by the significant increase in epithelial height, ST diameter and sperm count compared to group II. Furthermore, its protective effect was obvious in the interstitial cells of Leydig as well, in most of testicular sections, which showed normal appearance and increased AR expression. This was accompanied by restored activity in the form of release of more testosterone needed for normal spermatogenesis as enforced by significant increase in serum TH level compared to group II. However, some Leydig cells with darkly stained nuclei were observed in some STs and were reflected as minimal expression of $\mathrm{p} 53$.

In the present work, NG modulated the antioxidant status of the testis as proved by the significant reduction in MDA level versus group II indicating decreased rate of lipid peroxidation. This explanation was in line with several studies, which confirmed the antioxidative activity of $\mathrm{NG}^{[66,67]}$ and explained it by the ability of $\mathrm{NG}$ to induce the expression of many antioxidant-related genes ${ }^{[68]}$ and inhibit the activity of ROS-forming enzymes as NADPH oxidase $^{[69]}$. Additionally, some reporters suggested that NG could protect normal cells against radiation-induced apoptosis by modulating the expression of p53, Bax, and $\mathrm{Bcl}-2^{[70]}$. This was enforced in the present work, by 
significant reduction in number of $\mathrm{p} 53$ positive cells compared to mobile group.

The current study aimed also to detect the reversibility of mobile phone damaging effects on testes. The recorded significant decrease in serum TH and number of AR positive Leydig cells in the recovery group versus control signified the incomplete recovery of Leydig cells. Likewise, the decrease in area percent of CX43 immunoreaction versus control denoted that Sertoli cells didn't attain its full recovery, and this might affect Leydig cells as well because it was shown in a former study that the number and volume of Leydig cells were related to level of $\mathrm{Cx} 43^{[71]}$. This was supported by the fact that the Sertoli cell-derived factors are required to maintain the Leydig cells. Thus, Sertoli cells are crucial regulators of the two major functions of the adult testis spermatogenesis and androgen secretion ${ }^{[72]}$. This in turn, explains why spermatogenic cycle was still affected as appearance of partial loss of spermatogenic cells, detached apoptotic cells, multinucleated giant cells, expression of moderate amount of positive p53 immunoreactive cells and subsequent decrease in sperm count.

On the other hand, slight improvement was detected as an increase in the diagonal diameter of ST, height of spermatogenic epithelium, sperm count and number of PCNA positive cells and AR positive Leydig cells and area percent of CX43 versus mobile phone group, but the differences were statistically non significant. This partial improvements of these histological and morphometric findings could be attributed to the corresponded non significant elevation in serum testosterone and diminution of testicular MDA compared to mobile group. In the current study, the 56-days ( 8 weeks) recovery period was chosen based on the time necessary to complete a spermatogenic cycle in rats $^{[73,74]}$ as approximately 4.5 cycles (each about 12.9 days) are required for the basal spermatogonia to reach the final stage of spermatid development. Theoretically, this duration allows full recovery of all cell layers after exposure to reversible injury. However, there is often a lag period before all the cells can achieve full production capacity ${ }^{[75]}$. This might explain why complete recovery was not attained in the present work 56 days postexposure. So, more time might be required to overcome EMWs induced testicular toxicity.

\section{CONCLUSION}

Mobile phones might have deleterious effects on human reproductive health This was evidenced by the biochemical (MDA, TH and sperm count) and histopathological changes of testis reflected as impairment of spermatogenesis. Remarkably, these changes are partially recovered after stoppage of exposure to EMWs. This might be attributed due to the partial improvement of Leydig and Sertoli cells and consequently the process of spermatogenesis. Moreover, NG co-administration was protective through improvement of OS, testicular function and structure. Since, it might be difficult to avoid exposure to mobile phones EMWs therefore, routine consumption of citrus fruits rich in NG can efficiently counteracts OS and maintains reproductive health.

\section{CONFLICT OF INTEREST}

There are no conflicts of interest.

\section{REFERENCES}

1. Mahmood Z. E-government implementation and practice in developing countries. Advances in electronic government, digital divide, and regional development (AEGDDRD) book. 1st ed. Idea Group Inc (IGI); 2013. pp. 196.

2. Agarwal A, Singh A, Hamada A, Kesari K. Cell phones male infertility: a review of recent innovations in technology consequences. Int Braz J Urol. 2011; 37: 432-54.

3. Agarwal A, Deepinder F, Sharma RK, Ranga G, Li J. Effect of cell phone usage on semen analysis in men attending infertility clinic: an observational study. Fertil Steril. 2008; 89:124-8.

4. Stalin P, Abraham SB, Kanimozhy K, Prasad RV, Singh Z, Purty AJ. Mobile phone usage and its health effects among adults in a semi-urban area of Southern India .J Clin Diagn Res. 2016; 10: 14-16.

5. Karaman MI, Gokce AM, Koca O, Karaman B, ozturk MI, Yurdakul N, Ercan F. The effects of electromagnetic waves emitted by the cell phones on the testicular tissue. Arch Ital Urolrol. 2014; 30: 274-7.

6. Nitu. Histological changes in rat testes after long term exposure to mobile phone radiation. International Journal of All Research Education Scientific Methods (IJARESM). 2016; 4: 60-3.

7. Podder B, Song HY, Kim YS. Naringenin exerts cytoprotective effect against paraquat-induced toxicity in human bronchial epithelial BEAS2B cells through NRF2 Activation. J Microbiol Biotechnol. 2014; 24: 605-61.

8. Jain A, Yadav A, Bozhkov AI, Padalko VI, Flora SJ. Therapeutic efficacy of silymarin naringenin in reducing arsenic-induced hepatic damage in young rats. Ecotoxicol Environ Saf. 2011; 74: 607-14.

9. Reza Pashaei. Features of apigenin, luteolin, 
hesperetin and naringenin in crop and body. Int $\mathbf{J}$ Food Sci Nutr Diet. 2016; 5: 300-4.

10. Tsai SJ, Huang CS, Mong MC, Kam WY, Huang HY, Yin MC. Anti-inflammatory antifibrotic effects of naringenin in diabetic mice. J Agric Food Chem. 2012; 60:514-21.

11. Abaza MS, Orabi KY, Al-Quattan E, Al-Attiyah RJ. Growth inhibitory chemo-sensitization effects of naringenin, a natural flavanone purified from Thymus vulgaris, on human breast colorectal cancer. Cancer Cell Int. 2015; 15: 46.

12. Lee $\mathrm{S}$, Lee $\mathrm{CH}$, Moon SS, Kim E, Kim CT, Kim $\mathrm{BH}$, Bok SH, Jeong TS. Naringenin derivatives as anti-atherogenic agents. Bioorg Med Chem Lett. 2003; 13: 3901-3.

13. Kannappan S, Palanisamy N, Anuradha CV. Suppression of hepatic oxidative events regulation of eNOS expression in the liver by naringenin in fructose-administered rats. Eur J Pharmacol. 2010; 645: 177-84.

14. Wang C, Fan RQ, Zhang YX, Nie H, Li K. Naringenin protects against isoniazid- rifampicininduced apoptosis in hepatic injury. World $\mathrm{J}$ Gastroenterol. 2016; 28: 9775-83.

15. Meng LM, Ma HJ, Guo H, Kong QQ, Zhang Y. The cardioprotective effect of naringenin against ischemia-reperfusion injury through activation of ATP-sensitive potassium channel in rat. Can J Physiol Pharmacol. 2016; 94:973-8.

16. Roy S, Ahmed F, Banerjee S, Saha U. Naringenin ameliorates streptozotocin-induced diabetic rat renal impairment by downregulation of TGF- $\beta 1$ IL-1 via modulation of oxidative stress correlates with decreased apoptotic events. Pharm Biol. 2016; 54:1616-27.

17. Ganaie MA. The protective effects of naringenin on testes gonadotoxicity induced by cisplatin in rats. Bull Env Pharmacol Life Sci. 2015; 5: 15-21.

18. Mostafa HS, Abd El-Baset SA, Kattaia AA, Zidan RA, Al Sadek MM. Efficacy of naringenin against permethrin-induced testicular toxicity in rats. Int $\mathbf{J}$ Exp Pathol. 2016; 97:37-49.

19. El-Bediwi AB, Saad M, El-Kott AF, Eid E. Influence of electromagnetic radiation produced by mobile phone on some biophysical blood properties in rats. Cell Biochem Biophys. 2013; 65: 297-300.
20. El-Akabawy G, El-Kholy W: Neuroprotective effect of ginger in the brain of streprozotocininduced diabetic rats in Annals of Anatomy. 2014; 169: 119-28.

21. Mailnkot M, Kunnath AP, Jayalekshmi H, Koduru B, R.Valsalan. Radio frequency electromagnetic radtion (RF-EMR) from GSM $(0.9 \backslash 1.8 \mathrm{MHz})$ mobile phones induces oxidative stress and reduces sperm motility in rats. Clinics. 2009; 64: 561-5.

22. Ohkawa, H, Ohishi N, Yagi K. Assay for lipid peroxides in animal tissues by thiobarbituric acid reaction. Anal. Biochem. 1979; 95: 351-8.

23. Kiernan J. Histological and histochemical methods: theory and practice. 3rd ed. London, New York and New Delhi: Arnold publisher; 2001. pp. 111-62.

24. Hejmej A, Kopera I, Kotula-Balak M, Gizejewski Z, Bilinska B. Age dependent pattern of connexin 43 expression in testes of European bison (Bison bonasus L.). J Exp Zool A Ecol Genet Physiol. 2009; 311: 667-75.

25. O'Hara L, Smith LB. Androgen receptor roles in spermatogenesis and infertility. Best Pract Res Clin Endocrinol Metab. 2015; 29: 595-605.

26. Bancroft J, Gamble M. Theory and Practice of Histological Techniques. Staining methods. 7th ed. Edinburgh, London, Madrid, Melbourne, New York and Tokyo: Churchill Livingstone; 2008. pp. 263-325.

27. Emsley R, Dunn G, White IR. Mediation and moderation of treatment effects in randomised controlled trials of complex interventions. Stat Methods Med Res. 2010; 19: 237-270.

28. Sarookhani MR, Asiabanha Rezaei M, Safari A, Zaroushani V, Ziaeiha M. The influence of 950 $\mathrm{MHz}$ magnetic field (mobile phone radiation) on sex organ and adrenal functions of male rabbits. Afr J Biochem Res. 2011; 5: 77-80.

29. Ozguner F1, Altinbas A, Ozaydin M, Dogan A, Vural H, Kisioglu AN, Cesur G, Yildirim NG. Mobile phone-induced myocardial oxidative stress: protection by a novel antioxidant agent caffeic acid phenethyl ester. Toxicol Ind Health. 2005; 21:223-30.

30. Baharara J, Zafar-Balanejad S, Kamareh E, Asadi-Samani M. The effects of green tea 
extract on teratogenicity induced by low frequency electromagnetic field on bone marrow Balb/C miceembryo. J Herbmed Pharmacol. 2014; 3: 47-51

31. Giera M, Lingeman HW, Niessen M A. Recent advancements in the LC- and GC-based analysis of malondialdehyde (MDA): a brief overview. Chromatographia. 2012; 75: 433-40.

32. Ayala A, Munoz MF, Arguelles S. Lipid peroxidation: production, metabolism, and signaling mechanisms of Malondialdehyde and 4-Hydroxy-2-Nonenal. Oxid Med Cell Longev. 2014; 2014: 31 pages Article ID 360438

33. Bas H, Kalender S. Antioxidant status, lipid peroxidation and testis-histoarchitecture induced by Lead Nitrate and Mercury Chloride in male rats. Braz arch biol technol. 2016; 59: e16160151.

34. Sahoo DK, Roy A, Chainy GB. Protective effects of vitamin $\mathrm{E}$ and curcumin on L-thyroxineinduced rat testicular oxidative stress. Chem Biol Interact.2008; 176: 121-8.

35. Bin-Meferij MM, El-kott AF. The radioprotective effects of Moringa oleifera against mobile phone electromagnetic radiation-induced infertility in rats. Int J Clin Exp Med. 2015; 8: 12487-97.

36. Saygin M, Asci H, Ozmen O, Cankara FN, Dincoglu D, Ilhan I. Impact of $2.45 \mathrm{GHz}$ microwave radiation on the testicular inflammatory pathway biomarkers in young rats: The role of Gallic acid. Environ Toxicol. 2016; 31: 1771-84.

37. Hajioun B. Effects of cell phone radiation on testosterone levels and testicular changes in rats treated with garlic (Allium sativum L.) hydroalcoholic extract. Progress in Biological Sciences. 2014; 4: 63-72.

38. Ma HR, Cao XH, Ma XL, Chen JJ, Chen JW, Yang H, Liu YX. Protective effect of Liuweidihuang Pills against cellphone electromagnetic radiationinduced histomorphological abnormality, oxidative injury, and cell apoptosis in rat testes Zhonghua Nan Ke Xue. 2015; 21: 737-41.

39. Otitolojo AA, Obe IA, Adewale OA, Otubanjo OA, Osunkalu VO. Preliminary studies on the induction of sperm head abnormalities in mice, Mus musculus, exposed to radiofrequency radiations from global system from mobile communication base stations. Bulletin of Environmental Contamination Toxicology. 2010; $84: 51-4$
40. Meo SA, Arif M, Rashied S, Husain S, Khan MM, Vohra MS, Usmani AM, Imran MB, Al-Drees AM. Hypospermatogenesis and Spermatozoa Maturation Arrest in Rats Induced by Mobile Phone Radiation. JCPSP. 2011; 21: 262-5.

41. Aitken RJ, Bennetts LE, Sawyer D, Wiklendt AM, King BV. Impact of radio frequency electromagnetic radiation on DNA integrity in the male germline. Int J Androl 2005; 28: 171-9.

42. Moon KH, Shin HJ, Ahn HS, Kim JY, Shin SM, Yun SM, Hwang YD. Long-Term Exposure of Rats to $2.45 \mathrm{GHz}$ Electromagnetic Field: Effects on Reproductive Function, in: Magjarevic R, Nagel JH (eds) World Congress on Medical Physics and Biomedical Engineering 2006, IFMBE Proceedings, 4: 2767-9. Springer, Berlin, Heidelberg.

43. Pandey N, Giri S, Das S, Upadhaya P. Radiofrequency radiation (900 $\mathrm{MHz})$-induced DNA damage and cell cycle arrest in testicular germ cells in Swiss albino mice. Toxicology and Industrial Health. 2017; 33: 373-84.

44. Weyden VD, Arends MJ, Chausiaux OE. Loss of TSLC1 causes male infertility due to a defect at the spermatid stage of spermatogenesis. Molecular and Cellular Biology 2006; 26: 3595-609.

45. Pointis G, Gilleron J, Carette D, Segretain D. Testicular connexin 43, a precocious molecular target for the effect of environmental toxicants on male fertility. Spermatogenesis. 2011; 1: 303-17.

46. Weider K, Bergmann M, Brehm R. Connexin 43: its regulatory role in testicular junction dynamics and spermatogenesis. Histol Histopathol. 2011; 26: $1343-52$.

47. Lampe PD, Lau AF. The effects of connexion phosphorylation on gap junctional communication. Int J Biochem Cell Biol. 2004; 36: 1171-86.

48. Wong EWP, Cheng CY. Impacts of environmental toxicants on male reproductive dysfunction. Trends Pharmacol Sci. 2011; 32: 290-9.

49. Rato L, Socorro S, Cavaco JE, Oliveira PF. Tubular fluid secretion in the seminiferous epithelium: ion transporters and aquaporins in Sertoli cells. J Membr Biol. 2010; 236: 215-24.

50. Manivannan B, Mittal R, Goyal S, Ansari AS, Lohiya NK. Sperm characteristics and ultrastructure of testes of rats after long-term treatment with the methanol subfraction of Carica 
papaya seeds. Asian J Androl. 2009; 11:583-99.

51. Leon J, Acuna-Castroviejo D, Escames G, Tan DX, Reiter RJ. Melatonin mitigates mitochondrial malfunction. J Pineal Res. 2005; 38: 1-9.

52. Billig H, Furuta I, Rivier C, Tapanainen J, Parvinen $M$ and Hsueh AJ. Apoptosis in testis germ cells: developmental changes in gonadotropin dependence and localization to selective tubule stages. Endocrinology. 1995; 1: 5-12.

53. Woolveridge I, Morris ID. Apoptosis in toxicology. Editor. Roberts RJ. Taylor and Francis, New York. 2000; pp. 71-94.

54. Beumer TL, Roepers Gajadien HL, Gademan IS, van Buul PP, Gil-Gómez G, Rutgers DH, Rooij DG. The role of the tumor suppressor p53 in spermatogenesis. Cell Death Differ. 1998; 5: 669-77.

55. Rashed RM, Mohamed IK, EL-Alfy SH. Effects of two different doses of melatonin on the spermatogenic cells of rat testes: a light and electron microscopic study. Egypt J Histol 2010; 33: 819-35.

56. Meo SA, Al-Drees AM, Husain S, Khan MM, Imran MB. Effects of mobile phone radiation on serum testosterone in Wistar albino rats. Saudi Med J. 2010; 31: 869-73.

57. Toocheck C, Clister T, Shupe J, Crum C, Ravindranathan P, Lee TK, Ahn JM, Raj GV, Sukhwani M, Orwig KE, Walker WH. Mouse spermatogenesis requires classical and nonclassical testosterone signaling. Biol Reprod. 2016; 94:11.

58. Beardsley A., O’Donnell L. Characterization of normal spermiation and spermiation failure induced by hormone suppression in adult rats. Biol Reprod. 2003; 68: 1299-307.

59. Zhou Q, Nie R, Prins GS, Saunders PT, Katzenellenbogen BS, Hess RA. Localization of androgen and estrogen receptors in adult male mouse reproductive tract. $\mathrm{J}$ Androl. 2002; $23: 870-81$.

60. Wang, SM, Wang DW, Peng RY, Gao YB, Yang Y, Hu WH, Chen HY, Zhang YR, Gao Y. Effect of electromagnetic pulse irradiation on structure and function of Leydig cells in mice. Zhonghua Nan Ke Xue. 2003; 9: 327-30.
61. Manna PR, Soh JW, Stocco DM. The involvement of specific pkc isoenzymes in phorbol estermediated regulation of steroidogenic acute regulatory protein expression and steroid synthesis in mouse Leydig cells. Endocrinology 2011; 152: 313-25.

62. Zhou W, Wang XB, Yang JQ, Liu Y, Zhang GB. Influence of electromagnetic irradiation on P450scc mRNA expression in rat testis tissues and protective effect of the shield. Zhonghua Nan Ke Xue. 2005; 11: 269-71.

63. Oktem F, Ozguner F, Mollaoglu H, Koyu A, Uz E. Oxidative damage in the kidney induced by 900-MHz-emitted mobile phone: protection by melatonin. Arch Med Res. 2005; 36: 350-5.

64. Ozguner F, Bardak Y, Comlekci S. Protective effects of melatonin and caffeic acid phenethyl ester against retinal oxidative stress in long-term use of mobile phone: a comparative study. Mol Cell Biochem. 2006; 282: 83-8.

65. Li TR, Yang ZY, Wang BD, Qin DD. Synthesis, characterization, antioxidant activity and DNAbinding studies of two rare earth (III) complexes with naringenin-2-hydroxy benzoyl hydrazone ligand. Eur J Med Chem. 2008; 43: 1688-95.

66. Jagetia GC, ReddyTK. Modulation of radiation induced alteration in the antioxidant status of mice by naringin. Life Science. 2005; 77: 780-94.

67. Rajadurai M, Stanely P, Prince M. Naringin ameliorates mitochondrial lipidperoxides, antioxidants and lipids in isoproterenol-induced myocardial infarction in Wistar rats. Phytotherapy Research. 2009; 23: 358-62.

68. Renugadevi J, Prabu SM. Naringenin protects against cadmium-induced oxidative renal dysfunction in rats. Toxicology. 2009; $256,128-34$.

69. Ciz M, Denev P, Kratchanova M, Vasicek O, Ambrozova G, Lojek A. Flavonoids inhibit the respiratory burst of neutrophils in mammals. Oxid Med Cell Longev. 2012; 2012:181295.

70. Kumar S, Tiku AB. Biochemical and molecular mechanisms of radioprotective effects of naringenin, a phytochemical from citrus fruits. J Agric Food Chem. 2016; 64:1676-85.

71. Lampe PD, Lau AF. The effects of connexion 
phosphorylation on gap junctional communication. Int J Biochem Cell Biol. 2004; 36: 1171- 86.

72. Rebourcet D, O'Shaughnessy PJ, Monteiro A, Milne L, Cruickshanks L, Jeffrey N, Guillou F, Freeman TC, Mitchell RT, Smith LB. Sertoli cells maintain Leydig cell number and peritubular myoid cell activity in the adult mouse testis. PLoS One. 2014; 21; 9: e105687.

73. Russell LD, Ettlin RA, Sinha Hikim AP, Clegg ED. The classification and timing of spermatogenesis. In: Russell LD, editor. Histological and histopathological evaluation of the testis. 1st ed. Clearwater: Cache River Press; 1990. pp. 41-58.

74. Jegou B, Pineua C, Toppan J. Spermatogenesis in Vitro in Mammals. In: Assisted reproductive technology: Accomplishments and new horizons. Cambridge: Cambridge University Press; 2002. pp.3-6.

75. Creasy DM. Evaluation of testicular toxicity in safety evaluation studies: the appropriate use of spermatogenic staging. Toxicologic patology.1997; 25: 119-31. 


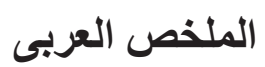

تأثير الموجات الكهرومغناطيسية للهاتف المحمول على خصية الجرذان والدور الوقائي المحتمل

ايمان عباس فرج، مروة محمد يسرى

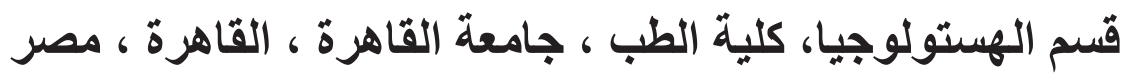

المقدمة: مع زيادة استخدام الهو اتف المحمولة، ارتفع الاهتمام بفحص المخاطر التي يمكن أن تؤثر على صحة الناس، والته والتي

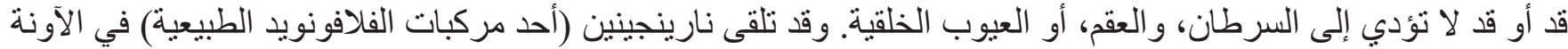

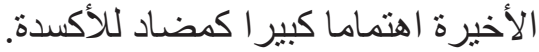

الههف من البحث: تقييم آثار استخدام الهاتف المحمول على خلى خصية الجرذان البالغة، وتطور التعافي التلقائي والدور الوقائي للنارينجينين ضد هذه الآثار. مواد وطرق البحث: تم تقسيم اربعة وعثرين من ذكور الجرذان البالغين إلى خمس مجمو عات. ( (1) الضابطة، (2) المحمول،

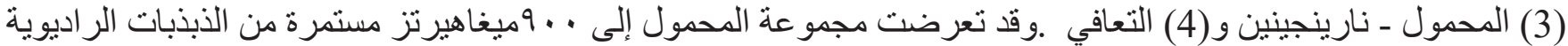

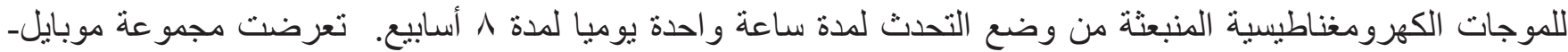

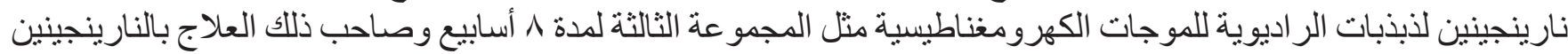

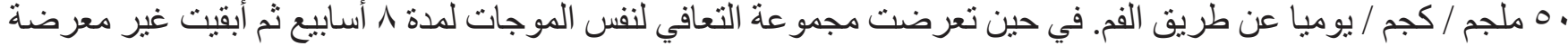

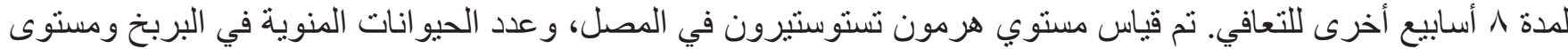

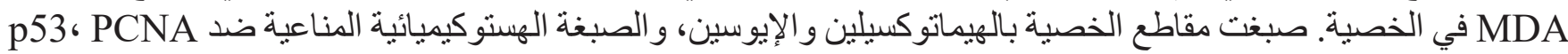
AR ، CX43 وتعرضت للقياسات المترية الثكلية وحللت إحصائيا.

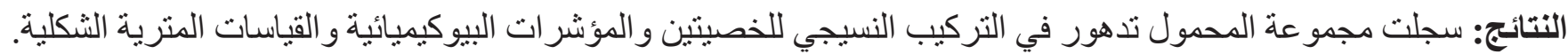

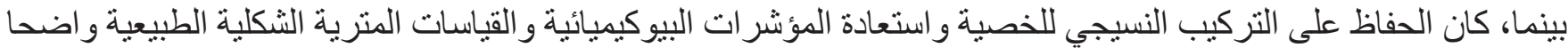
في المجموعة الر ابعة. من ناحية أخرى، أظهرت مجموعة التعافي تحسن غير كامل حيث لوحظ بعض التأثر في الخصية.

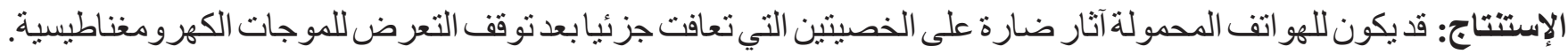
ومع ذللك، كان إعطاء النارينجينين المصاحب لهاو اقاقيا. 